\title{
Students' Perceptions on the University Social Responsibilities of a Malaysian Private University: Does Gender Matter?
}

\section{Tak Jie Chan, Hon Tat Huam \& Abu Bakar Sade}

To Link this Article: http://dx.doi.org/10.6007/IJARBSS/v11-i9/10754

DOI:10.6007/IJARBSS/v11-i9/10754

Received: 09 July 2021, Revised: 27 July 2021, Accepted: 15 August 2021

Published Online: 20 September 2021

In-Text Citation: (Chan et al., 2021)

To Cite this Article: Chan, T. J., Huam, H. T., \& Sade, A. B. (2021). Students' Perceptions on the University Social Responsibilities of a Malaysian Private University: Does Gender Matter? International Journal of Academic Research in Business and Social Sciences, 11(9), 1460-1473.

Copyright: @ 2021 The Author(s)

Published by Human Resource Management Academic Research Society (www.hrmars.com)

This article is published under the Creative Commons Attribution (CC BY 4.0) license. Anyone may reproduce, distribute, translate and create derivative works of this article (for both commercial and non-commercial purposes), subject to full attribution to the original publication and authors. The full terms of this license may be seen at: http://creativecommons.org/licences/by/4.0/legalcode

Vol. 11, No. 9, 2021, Pg. 1714 - 1473

Full Terms \& Conditions of access and use can be found at http://hrmars.com/index.php/pages/detail/publication-ethics 


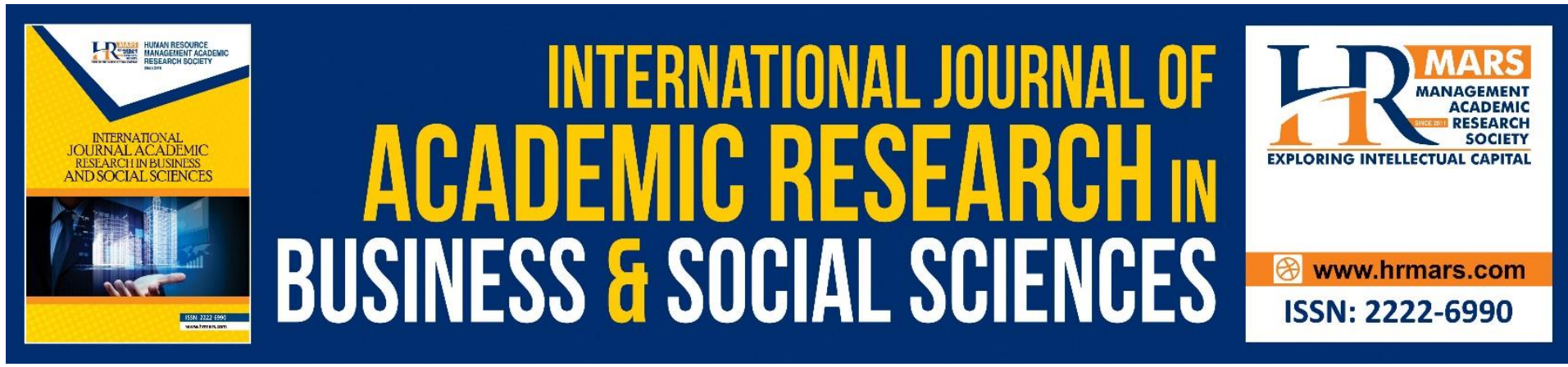

\title{
Students' Perceptions on the University Social Responsibilities of a Malaysian Private University: Does Gender Matter?
}

\author{
Tak Jie Chan \\ ${ }^{1}$ Putra Business School, 43400 UPM, Serdang, Selangor, Malaysia, ${ }^{2}$ Faculty of Business, \\ Accountancy, Communication \& Hospitality Management, SEGi University, 47810, Petaling \\ Jaya, Selangor, Malaysia \\ Email: takjie.phd_mkt18@grad.putrabs.edu.my,chantakjie@segi.edu.my
}

Hon Tat Huam \& Abu Bakar Sade

Putra Business School, 43400 UPM, Serdang, Selangor, Malaysia

Email: huam@putrabs.edu.my, abubakar.sade@putrabs.edu.my

\begin{abstract}
University social responsibility (USR) has emerged tremendously as an important area supporting the Sustainable Development Goals (SDGs). Today, universities have realized the significance of being ethical in their operations to attract various stakeholders, especially the students (customers). However, the influence of social responsibility practices in university settings remains understudied as USR is a newly emerging concept. The purpose of this study was to examine the students' perception of USR and test the gender difference in the perception of USR responsibilities in one of the private universities in Klang Valley. A survey method was employed using purposive sampling. Questionnaires were distributed and generating 400 valid responses. The data were then analyzed using a one sample t-test and an independent sample t-test through the Statistical Package for the Social Sciences (SPSS) version 25.0. Based on the findings, ethical USR responsibilities were perceived favorably by the respondents. However, respondents did not agree with some of the items in the philanthropy USR responsibilities. In addition, the independent sample t-test results revealed no significance difference in term of gender in perceiving the ethical and philanthropy responsibilities. The study contributed to the short-form USR measure that is newly developed by testing it empirically in the Malaysian context. The university's management will also benefit from the USR initiatives, as it help shape students' favorable perception of the institution. It serves as a strategic marketing and branding tool in customer relationship management to attractive potential students and retain the current ones.
\end{abstract}

Keywords: Gender, Private higher Education Institution, Students' Perceptions, Sustainability, University Social Responsibilities 


\section{Introduction}

In this contemporary era where the globe focuses on the Sustainable Development Goals (SDGs), there is a growing interest in social responsibility in university settings (Latif, 2018; Saleh et al., 2021; Sunardi, 2019). Social responsibility initiatives have set a new trend in the university market. Thus, the citizenship and sustainability initiatives of firms or institutions are significant in meeting the Key Performance Indicators (KPIs) (Hristov \& Chirico, 2019) and fulfilling the minimum quality assurance (QA) standards (Plungpongpan, Tiangsoongern \& Speece, 2016). In addition, in Malaysia HEls, one aspects that contribute to the public and private university's ranking is based on university social responsibility (USR) highlighted in the services and income generation of SETARA rating (Education Malaysia Global Services, n. d.).

This has supported the notion of Ramos-Monge et al (2017) that many HEls are likely to adopt the business approach to survive in the turbulent environment. Therefore, universities are jumping into the bandwagon, and more universities adapt to these business approaches due to the marketization and privatization of the universities (Mohamad, Ismail \& Bidin, 2017), where universities have become the current $21^{\text {st }}$ century business entities (Chang, Sirat \& Abdul Razak, 2018). This has further supported the notion that adopting the social responsibility concept towards sustainability in the Malaysian university context has become a pivotal agenda that requires further investigation (Chan \& Huam, 2019; Chan \& Hasan, 2018).

In Malaysia, private education sectors are generally profit-generated in nature. Hence, meeting with the profit is prominent in Malaysian private educational institutions (Jayabalan, Dorasamy \& Raman, 2021), and the Malaysian private higher learning institutions face numerous challenges in terms of academics, facilities, students, programs and curriculum, competition, accreditation, finance and research (Anis, Islam \& Abdullah, 2018). However, the lack of regulations and policies has raised the question of the significance and relevancy of the USR initiatives by the HEls, whereby most USR initiatives in HEls remain voluntary acts. Most important, Dusingize and Nyiransabimana (2017) stressed that the operationalization of the terminology of USR for educational institutions is still lacking as it is a newly emerging concept (Gómez et al., 2018). In addition, Symaco and Tee (2019) highlighted that social responsibility and sustainable development are not fully integrated into the core initiatives of the universities among the ASEAN countries.

Furthermore, in the context of universities, students' attitude and behavior towards the USR initiatives implemented by the university's management in the developing nation is still insufficient (El-Kassar, Makki \& Gonzalez-Perez, 2019). Larran-Jorge, Hernandez and Cejas (2012) supported the notion by arguing that academic research of USR and its influence on university stakeholders are still scarce. Hence, the USR initiatives require further investigation, especially in the universities of the developing countries, particularly in the Malaysia setting (Chan \& Huam, 2019; Chan \& Hasan, 2018; Senin, Halim \& Ali, 2019).

Hence, the current study focuses on the current students as they are the major stakeholders of the university and universities unable to survive without the students (Dagilienè \& Mykolaitienè, 2015; Geryk, 2016). Furthermore, researchers argued that students give more attention to USR practices than other university stakeholders (Kouatli, 
2019, Latif et al., 2021), which justified examining students as the institution's main stakeholder. In addition, previous studies have argued that gender plays a significant role when it comes to perceiving the social responsibility practices, where female students will be paying more attention to the social responsibility initiatives as compared to male students (Berényi \& Deutsch, 2017; Lu et al., 2020), while other studies found that gender did not influence students' perception on the social responsibility (Teixeira et al., 2018).

Past studies on social responsibility mainly focused on a four-dimensional pyramid model in which Carroll (1979) emphasized that CSR comprises economic, legal, ethical, and philanthropic responsibilities. However, USR dimensions that focus on the specific dimensions relevant to the emerging economies, such as 1) ethical responsibilities, 2) research responsibilities, and 3) philanthropy responsibilities, required further extension of study (Latif, 2018; Latif et al., 2021). Most importantly, these items are pertinent in Malaysia as a developing country because the items were compiled and collated from existing global social responsibility best practices measured in the education industry.

Based on the voids highlighted, the current study aims to examine the student's perception of the ethical and philanthropy dimension of USR in a private university in Malaysia. In addition, the current study also wishes to test the difference of perceived USR dimensions by gender.

\section{Literature Review}

\section{Social Responsibility in University Context}

SDGs have been a topic of interest in sustainability, which urged the universities to participate with it. Hence, universities play a pivotal role in disseminate the knowledge regarding the SR issues and should go beyond to advocate the public and stakeholders to support the SDG initiatives (Leal Filho et al., 2019). This has further aligned with the study of Biswas and Chandra (2019), where they highlighted that universities could play a significant role in upholding social responsibility practices through diverse strategies. By gauging sustainability initiatives, the universities can evaluate their commitment and push for positive changes, especially among the students, as the young generation are important change agents (Pätäri et al., 2017). Hence, it can be concluded that green practices can serve as a benchmark for measuring the performance and progress of universities towards SDG goals.

Da Silva et al (2018) intended to develop a set of sustainability indicators applied to Brazilian Higher Education Institutions (HEINS). The study employed qualitative design, wherein the data was collected through (semi-structured interviews, documentary research, observations) and content analysis and validate through the triangulation process. The qualitative study results proposed that sustainability indicators for HEINS comprised of four subcategories, namely institutional, university management, financial, and social \& environmental responsibility.

Păunescu, Drăgan and Găucă (2017) examined the USR based on the QS starts bestranked universities, and the findings revealed that USR practices include community investment and development, social work and disaster relief, regional human capital development, and environmental impact. The above notion has urged the universities under study to establish the co-value creation with its key stakeholders to ensure its survival and sustainability. 
Spodarczyk and Szelągowska-Rudzka (2019) examined the social responsibility initiatives from the student's perspectives. Five dimensions have been identified, namely values, relations, graduate, education, and efficient organization. The results revealed that education is the most pivotal facet perceived by the students. The discussion urged the university to foster the SRS because this will produce a graduate that competitive in the labor market.

Junior et al (2019) investigated undergraduate management's students' opinions about corporate social responsibility (CSR) and sustainability in a university in Brazil. Descriptive and non-parametric analysis was carried out, and results indicate that the economic dimension predominates over the other CSR dimension. Imbrișcă and Toma (2020) intend to examine the relationship between factors that motivate students to involve in social responsibility initiatives in Romania higher education institutions. The study utilized students from the Faculty of Business and Administration as the sample and analyzed using factorial and logit regression analysis. The findings found that personal values were the main determinant, whereas structural and interpersonal barriers were the main inhibitors. The results demonstrate that the social responsibility activities contribute to sustainable development via students' active engagement and participation.

In addition, Larrán, Andrades and Herrera (2018) investigated the perceptions and attitudes of business and accounting students toward CSR and sustainability in the Spanish context. A survey was administered to Spanish business and accounting students, and 319 valid responses were received. The findings indicated that business and accounting students demonstrated a greater concern for the social and environmental dimensions of the CSR and sustainability term. Based on the discussion above, it can be said that the differences in the perception and attitudes, and how the students perceived the social responsibility initiatives depends on the university's cultural, socioeconomic, legal and commitment.

Meanwhile, Rad, Parsa, Shahi and Bahrami (2020) analyze the USR in the context of Iran showed that the USR is a notable development of respect to the environment, the respect of national and international peace culture, a commitment to end poverty and striving balance for social and economic issues. In addition, the results also illustrate that universities as organizations need to respond to USR by reviewing the curriculum development, reforming the core missions of the university, and recreation of the university's culture to align with its social responsibilities. In addition, Latif (2018) highlighted that USR could be measured based on how well a university focuses on its ethical responsibilities, takes its research/development responsibilities seriously, and commits to philanthropy. Thus, it can be said that USR is a university's commitment to recognize the interest of its stakeholders and society, and improve its stakeholders' well-being through quality educational services.

\section{Ethical Responsibilities}

Ethics provide the standards on how individuals or businesses should behave, and it covers areas beyond laws and legal systems. Ethical responsibility is the ability to recognize, interpret and act upon multiple principles and values according to the standards within a given field (Juščius \& Snieška, 2008).

\section{Philanthropy Responsibilities}

Philanthropic responsibility consists of donating funds, goods, services to another organization or cause, such as to the poor and homeless people. Mohr, Webb and Harris (2001) defined philanthropic CSR as delivering values to the community and public that have 
less or no association to the business or company. In other words, this is to do greater values for the society and humanity as the contribution given back to the society it operates.

\section{Gender and Social Responsibility}

Berényi and Deutsch (2017) investigated the role of gender in perceived CSR attitudes among Hungarian business students. The study found that male and female students have different perceptions and attitudes towards the CSR carried out by the university and indicated that female students give more attention to CSR issues than male students. This has further supported Ugwuozor (2020) notion that exposure to business ethics education has a significant effect on gender, implying that male and female students have different perspectives on CSR issues in the Nigerian context.

In addition, Lu et al., (2020) wish to examine the gender difference in CSR implementation in Lithuanian small-medium enterprises (SMEs). The results revealed that female managers were more convinced of the benefits of the implementation of CSR initiatives, making them perceived CSR more favorable than male managers. In contrast, Teixeira et al., (2018) found that students' perceptions of CSR were not statistically significant with the demographic variables, including gender.

Bhullar (2019) investigated the perceptions of MBA second year students regard CSR for sustainable development, and the findings revealed that marketing male students have a high level of perception of CSR, whereas marketing female students have low levels. In contrast, the female finance students perceived CSR as high, compared to the finance male students who showed an average level of perception towards CSR, and some of the business students have low levels of perception towards CSR. Based on the above discussion, it can be concluded that gender has different perspectives to the CSR depends on the economic and cultural settings, which hypothesized that:

$\mathrm{H}_{1}$ : There is a significant difference between male and female students regarding their perception of the USR initiatives.

\section{Methodology \\ Research Design}

This study employed a quantitative (survey) design, where structured questionnaires were distributed to students. In this study, survey design was a suitable method as it allows the researcher to effectively find out the respondents' opinions on a particular phenomenon (Babbie, 2020).

\section{Sampling Procedures}

This study utilized a non-probability sampling method where purposive sampling was applied. The concept of purposive sampling focuses on subjects who possess a particular characteristic that could help the research (Etikan, Musa \& Alkassim, 2016). Hence, the respondents must be currently pursuing their study at University $X$ in order for them to know better regard the social responsibilities of University $X$. For this study, the researchers were unable to get the sampling frame and know the students' exact population. Hence, the study yielded four hundred valid responses, and it was deemed sufficient and supported the notion of Sekaran and Bougie (2016), who recommended that sample sizes between 30 and 500 are still sufficient for business and social science studies. 


\section{Measurement}

The questionnaire consisted of two (2) sections. Section A was a demographic section, and Section B included items pertaining on USR comprising the two dimensions, namely, ethical and philanthropic responsibilities. Section A was designed to solicit demographic profiles of the respondents such as gender, type of students, age, race, and education level. Section B comprised the dimensions of short-form USR, namely ethical and philanthropic responsibilities adapted from (Latif, 2018; Latif et al., 2021). For section B, the researchers used the five-point Likert-type scale with (1) Strongly disagree, (2) Disagree, (3) Somewhat agree, (4) Agree, and (5) Strongly agree to measure the variables.

\section{Pilot Testing}

In measuring the reliability and consistency of the data gathered, Cronbach Alpha values are used as the indicator of measurement. Based on Saunders, Lewis and Thornhill (2019), the criteria that determine the acceptance of the reliability of the data is when the coefficient value under the Cronbach Alpha is higher than 0.70. Based on the study carried out, the scales used in this study are consistently reliable, with Cronbach's Alpha values that range from 0.725 to 0.798 , as shown in Table 1.

Table 1: Cronbach's alpha of the variables

\begin{tabular}{|c|c|c|c|}
\hline \multirow[b]{2}{*}{ Variables } & \multirow[b]{2}{*}{$\begin{array}{c}\text { Number of } \\
\text { Items }\end{array}$} & \multicolumn{2}{|c|}{ Cronbach's alpha } \\
\hline & & Pre-Test $(n=36)$ & $\begin{array}{l}\text { Post-test } \\
(n=400)\end{array}$ \\
\hline Ethical responsibilities & 4 & 0.725 & 0.778 \\
\hline Philanthropy responsibilities & 4 & 0.798 & 0.772 \\
\hline
\end{tabular}

\section{Normality Analysis}

To assess if the distributed data was normal or vice versa, Skewness and Kurtosis were used. According to Hair Black, Babin and Anderson (2018), it is important to ensure that the data is normally distributed before conducting a multivariate analysis. Considering $5 \%$ of sampling errors, the values for skewness and kurtosis should range from -2 to +2 for the data to be regarded as normally distributed (Siddiqi, 2014). Based on Table 2, the data is normally distributed as the skewness and kurtosis for the variables ranged between -2 to +2 . Therefore, an inferential statistic such as a t-test could be carried out.

Table 2: Skewness and Kurtosis of the variables

\begin{tabular}{lcccc}
\hline Variables & Min & Max & Skewness & Kurtosis \\
\hline Ethical responsibilities & 4 & 20 & -0.327 & -0.075 \\
Philanthropy & 4 & 20 & -0.188 & -0.524 \\
responsibilities & & & & \\
\hline
\end{tabular}

\section{Results and Discussion}

Based on Table 3 below, there is a relatively equal distribution of gender, where male students are slightly higher (54.0\%) than female students, which made up $46.0 \%$. More than half of the respondents are local students (61.3\%). In terms of age group, the majority of the respondents ranged from $20-24$ years old $(79.8 \%)$, followed by respondents aged $25-29$ years old (14.0\%). This indicated that the respondents of the study were made up of the young age group. For the races, there is an almost equal distribution of the respondents, as Chinese 
(26.8\%), Indians (25.3\%), the remaining respondents were of other ethnicities (28.5\%), and Malay made up $19.5 \%$. A majority, $76.8 \%$ of the respondents, are Bachelor's degree students, whereas 14.2\% studied Foundation/ Diploma, 6.3\% pursuing on the Master's Degree, and 2.8 $\%$ currently pursuing Ph.D, which indicated that the respondents were educated and able to make correct judgements on the issue.

Table 3: Demographic profile of respondents

\begin{tabular}{|c|c|c|c|}
\hline \multicolumn{2}{|l|}{ Variables } & \multirow{2}{*}{$\begin{array}{c}\text { Frequency } \\
216\end{array}$} & \multirow{2}{*}{$\begin{array}{c}\text { Percentage } \\
54.0\end{array}$} \\
\hline Gender & Male & & \\
\hline & Female & 184 & 46.0 \\
\hline & Total & 400 & 100.0 \\
\hline \multirow[t]{3}{*}{ Student } & Local & 245 & 61.3 \\
\hline & International & 153 & 38.3 \\
\hline & Total & 398 & 99.5 \\
\hline \multirow[t]{6}{*}{ Age } & $20-24$ & 319 & 79.8 \\
\hline & $25-29$ & 56 & 14.0 \\
\hline & $30-34$ & 14 & 3.5 \\
\hline & $35-39$ & 8 & 2.0 \\
\hline & $40-44$ & 3 & 0.8 \\
\hline & Total & 400 & 100.0 \\
\hline \multirow[t]{5}{*}{ Race } & Malay & 78 & 19.5 \\
\hline & Chinese & 107 & 26.8 \\
\hline & Indian & 101 & 25.3 \\
\hline & Other & 114 & 28.5 \\
\hline & Total & 400 & 100.0 \\
\hline \multirow[t]{5}{*}{ Education } & Foundation/Diploma & 57 & 14.2 \\
\hline & Bachelor Degree & 307 & 76.8 \\
\hline & Master Degree & 25 & 6.3 \\
\hline & Ph.D. & 11 & 2.8 \\
\hline & Total & 400 & 100.0 \\
\hline
\end{tabular}

\section{Ethical Responsibilities}

A one-sample t-test for each item of the ethical responsibilities was conducted to determine how students perceive ethical responsibilities. The results below indicated that the overall mean score for the ethical responsibilities is significant. Specifically, as displayed in Table 4, the overall mean of the ethical responsibilities $(M=3.351, S D=0.779, t=9.018, p=0.000)$ are significant with all the items under the ethical responsibilities. The highest mean for the item is that 'The university has reduced consumption of scarce resources, such as water and electricity' $(M=3.443, S D=1.067, t=8.290, p=0.000)$. The lowest mean score is for the item 'The university is committed to prevent pollution on all major environmental aspects' $(M=$ $3.240, S D=1.022, t=4.695, p=0.000$ ). This further concludes that there is an inclination towards agreement of ethical responsibilities of USR by the students. 
Table 4: One Sample T-Test for ethical responsibilities

\begin{tabular}{lccccc}
\hline Items & ${ }^{*} \boldsymbol{M}$ & $\boldsymbol{S D}$ & ${ }^{* *} \boldsymbol{t}$ & $\boldsymbol{d f}$ & $\boldsymbol{p}$ \\
\hline $\begin{array}{l}\text { The university ties to perform in a manner } \\
\text { consistent with expectations of societal and } \\
\text { ethical norms. }\end{array}$ & 3.393 & 0.952 & 8.249 & 399 & 0.000 \\
$\begin{array}{l}\text { The university has reduced consumption of scarce } \\
\text { resources, such as water and electricity. }\end{array}$ & 3.443 & 1.067 & 8.290 & 399 & 0.000 \\
$\begin{array}{l}\text { The university encourages its student initiatives } \\
\text { towards good environmental performance. }\end{array}$ & 3.330 & 0.976 & 6.759 & 399 & 0.000 \\
$\begin{array}{l}\text { The university is committed to prevent of } \\
\text { pollution on all major environmental aspects. }\end{array}$ & 3.240 & 1.022 & 4.695 & 399 & 0.000 \\
\hline Overall mean of ethical responsibilities & $\mathbf{3 . 3 5 1}$ & $\mathbf{0 . 7 7 9}$ & $\mathbf{9 . 0 1 8}$ & $\mathbf{3 9 9}$ & $\mathbf{0 . 0 0 0}$ \\
\hline
\end{tabular}

*On a 5-point Likert-type like scale, where 1 = Strongly disagree, $2=$ Disagree, 3 = Somewhat agree, 4 = Agree, and 5 = Strongly Agree

$* *$ Test value $=3$

\section{Philanthropy Responsibilities}

Table 5 displays the results of the one-sample t-test for the philanthropy USR. The overall mean for the philanthropy responsibilities $(M=3.109, S D=0.867, t=2.524, p=0.000)$ was significant with two items. Overall, the highest item of philanthropy responsibilities presents as 'The university participates in voluntary and charitable activities within the local community' ( $M=3.390, S D=0.983, t=7.939, p=0.000$ ). However, students did not agree with the item 'The University understand and offers more time for students to pay their fees if they are in financial difficulty' $(M=2.890, S D=1.252, t=-1.758, p=0.080)$ as well as the item 'The university offers financial support to students for extra-curricular activities' $(M=$ $3.015, S D=1.130, t=0.265, p=0.791)$. This concludes that students somewhat agree with the philanthropy aspects of USR.

Table 5: One Sample T-Test for philanthropy responsibilities

\begin{tabular}{|c|c|c|c|c|c|}
\hline Items & ${ }^{*} M$ & $S D$ & ${ }^{* *} \boldsymbol{t}$ & $d f$ & $p$ \\
\hline $\begin{array}{l}\text { The university offers scholarships to those in } \\
\text { need. }\end{array}$ & 3.143 & 1.118 & 2.549 & 399 & $\begin{array}{c}0.01 \\
1\end{array}$ \\
\hline $\begin{array}{l}\text { The university understand and offers more time } \\
\text { for students to pay their fees. }\end{array}$ & 2.890 & 1.252 & -1.758 & 399 & $\begin{array}{c}0.08 \\
0\end{array}$ \\
\hline $\begin{array}{l}\text { The university offers financial support to } \\
\text { students for extra-curricular activities. }\end{array}$ & 3.015 & 1.130 & 0.265 & 399 & $\begin{array}{c}0.79 \\
1\end{array}$ \\
\hline $\begin{array}{l}\text { The university participates in voluntary } \\
\text { charitable activities within the local community. }\end{array}$ & 3.390 & 0.983 & 7.939 & 399 & $\begin{array}{c}0.00 \\
0\end{array}$ \\
\hline Overall mean of philanthropy responsibilities & 3.109 & 0.867 & 2.524 & 399 & $\begin{array}{c}0.01 \\
2\end{array}$ \\
\hline
\end{tabular}

*On a 5-point Likert-type like scale, where 1 = Strongly disagree, $2=$ Disagree, 3 = Somewhat agree, 4 = Agree, and 5 = Strongly Agree

$* *$ Test value $=3$

The current results were congruent with the study of (da Silva et al., 2018; Larrán et al., 2018, Rad et al., 2020), which highlighted that the environmental, social, and philanthropy aspects of social responsibility were the domains being perceived favorably by the respondents. The 
current study found there is a positive perception of students on the two dimensions of USR. However, the students did not agreed on items in philanthropy responsibilities, especially related to the financial aspect, where university financial support the students to do the curricular activities. The university did not allows students to pay the fees late even students had some financial difficulties. The plausible explanation is that the current study is focused on a private university, where the bottom line is still the main concern to ensure the university can operate smoothly as private universities are like corporate entities (Ramos-Monge et al., 2017).

For the ethical responsibilities, male students $(M=13.472, S D=3.235)$ scored slightly higher than females $(M=13.326, S D=2.978)$ as shown in Table 6, $t(398)=0.467, p=.641$. On the other hand, male students $(M=12.607, S D=3.528)$ also scored slightly higher than the females $(M=12.239, S D=3.392)$ for the philanthropy responsibilities. Based on the independent sample t-test, $t(398)=1.056, p=0.291$. Since the significant value $(p)$ was greater than the significance level, $\mathrm{H} 1$ was rejected. It can be concluded that there are no significant difference between male and female students regarding their perception of ethical and philanthropy responsibilities.

Table 6: Independent sample t-test of ethical and philanthropy responsibilities by gender

\begin{tabular}{llccccc}
\hline & Gender & $\boldsymbol{M}$ & $\boldsymbol{S D}$ & $\boldsymbol{t}$ & $\boldsymbol{d f}$ & ${ }^{*} \boldsymbol{p}$ \\
\hline $\begin{array}{l}\text { Ethical } \\
\text { responsibilities }\end{array}$ & Male & 13.472 & 3.235 & & & \\
& & & & & & \\
& Female & 13.326 & 2.978 & & & \\
\hline $\begin{array}{l}\text { Philanthropy } \\
\text { responsibilities }\end{array}$ & Male & 12.607 & 3.528 & & & \\
& & & & & & \\
& Female & 12.239 & 3.392 & & & \\
& & & & & & \\
& & & & & & \\
\hline
\end{tabular}

*Note: 2-tailed test

The independent sample t-test results were aligned with Teixeira et al., (2018) study, where they found gender is not statistically significant with the students' perception of CSR. The possible explanation is that the current demographic of the respondents are mainly made up of young students, where their understanding and attitudes towards social responsibility might still be at the early stage and male and females students perceived the USR in a similar way which made the current study contradicted with past studies (Berényi \& Deutsch, 2017; Ugwuozor, 2020).

In summary, USR initiatives are important marketing strategies for universities in this $21^{\text {st }}$ century. Based on the empirical data, respondents perceived ethical USR responsibilities favorably. However, the students are not well perceived some of the items of philanthropy USR responsibilities, especially regarding the financial aspects to support the student extracurricular activities.

The current study contributes to the body of knowledge in the field of social responsibility, where the short-form of USR dimensions proposed by (Latif, 2018; Latif et al., 2021) is found pertinent in the Malaysian private university setting, whereby the USR, which focus on the multi-faceted is scarce and less explored.

The current results help the university management understand that USR initiatives can serve as a marketing and branding strategies in terms of practical implications. Hence, the university 
should encourage active participation from their students to enroll in various social responsibility activities by allocating budget and finance the student's clubs, thereby giving back to society and stakeholders. In addition, providing scholarships and having endowment funds for the students from the lesser advantaged group or indigenous ethics, and allowing students to pay the fees late if they face difficulties through installment payments are encouraging efforts of USR. This involvement is crucial as it differentiates the university from its rivals, thereby making the university a sustainable institution in the eyes of the stakeholders.

However, there are several limitations to the study. The current study was only limited to examine the USR initiatives from one private university in Malaysia. Future studies can include more private universities in Malaysia to add varieties in research perspectives and increase the validity. In addition, the comparative research on the practices of USR initiatives by public and private universities is timely as it will provide greater information and understanding of USR practices in developing countries.

Lastly, future studies may include the sub-dimension of the short-form USR research, as the current study only examined the two dimensions. Future studies can test the USR dimensions with various outcome variables such as university image, student satisfaction, student retention, and test the moderating or mediating effects to enhance the advancement of knowledge in the field of sustainability and green practices, particularly in educational institutions.

Note: This work is part of the doctoral studies of the first author.

\section{References}

Anis, A., Islam, R., \& Abdullah, N. A. (2018). Challenges faced by Malaysian private HLIs in providing quality education: A thematic analysis. Quality Assurance in Education, 26(3), 349-373. doi: 10.1108/QAE-10-2015-0039

Babbie, E. R. (2020). The practice of social research (15 th ed.). Cengage Learning.

Berényi, L., \& Deutsch, N. (2017). Gender differences in attitudes to corporate social responsibility among Hungarian business students. WSEAS Transactions on Business and Economics, 14, 298-310.

Bhullar, M. (2019). Investigating corporate social responsibility perceptions for sustainable development. Bioscience Biotechnology Research Communications, 12(3), 772-778. http://dx.doi.org/10.21786/bbrc/12.3/33

Biswas, J. K., \& Dash, M. C. (2019). Building a green image: Best sustainability practices in universities. Science and Culture, 85(9/10), 308-314. https://doi.org/10.36094/sc.v85.2019.BuildingaGreenImage.BiswasandDash.308

Carroll, A. B. (1979). A three-dimensional conceptual model of corporate social performance. Academy of Management Review, 4(4), 497-505. doi: 10.5465/AMR.1979.4498296

Chan, T. J., \& Huam, H. T. (2019). Predictors of reputation through university social responsibility practices in a Malaysian private university: The customer's perspective. Jurnal Komunikasi: Malaysian Journal of Communication, 35(3), 316-333. https://doi.org/10.17576/JKMJC-2019-3503-19

Chan, T. J., \& Mohd Hasan, N. A. (2018). Corporate social responsibility practices from the employees' perspective: A case of Malaysian higher education institution. International Journal of Academic Research in Business and Social Sciences, 8(4), 131153. doi: $10.6007 /$ IJARBSS/v8-i4/4003 
Chang, D. W., Sirat, M., \& Abdul Razak, D. (2018). Education in Malaysia towards a developed nation. Economic Working Paper, 1-19. Retrieved from https://www.iseas.edu.sg/images/pdf/ISEASEWP2018-4Wan.pdf

da Silva Jr., A., Martins-Silva, P. de O., de Araújo Vasconcelos, K. C., da Silva, V. C., de Melo, M. R., \& Dumer, M. C. R. (2018). Sustainability indicators for the Management of Brazilian Higher Education Institutions. Brazilian Administration Review, 15(3), 1-23. doi.org/10.1590/1807-7692bar2018180003

Dagilienè, L., \& Mykolaitienè, V. (2015). Disclosure of social responsibility in annual performance reports of universities. Procedia Social and Behavioural Sciences, 213, 586-592. https://doi.org/10.1016/j.sbspro.2015.11.454

Dusingize, M., \& Nyiransabimana, V. (2017). A study of university social responsibility (USR) practices at Rwanda's Institut Catholique de Kabgayi in Pompper, D. (Ed.). Corporate Social Responsibility, Sustainability, and Ethical Public Relations (The Changing Context of Managing People) (pp.143-166), Emerald Publishing Limited. doi.org/10.1108/978-1-78714-585-620181006

Education Malaysia Global Services (n. d.). SETARA rating. Retrieved on August, 7, 2021 from https://educationmalaysia.gov.my/setara-rating/

El-Kassar, A. N., Makki, D., \& Gonzalez-Perez, M. A. (2019). Student-university identification and loyalty through social responsibility: A cross-cultural analysis. International Journal of Educational Management, 33(1), 45-65. doi: 10.1108/IJEM-02-2018-0072

Etikan, I., Musa, S. A., \& Alkassim, R. S. (2016). Comparison of convenience sampling and purposive sampling. American Journal of Theoretical and Applied Statistics, 5(1), 1-4. doi: 10.11648/j.ajtas.20160501.11

Geryk. M. (2016). Social responsibility of the university. Gdansk: Gdansk Management College. Gómez, L., Pujols, A., Alvarado, Y., \& Vargas, L. (2018). Social responsibility in higher educational institutions: An exploratory study. In D. Crowther, S. Seifi, \& A. Moyeen (Eds.), The goals of sustainable development. Approaches to global sustainability, market, and governance (pp. 215-230). Singapore: Springer.

Hair, J. F., Black, W. C., Babin, B. J., \& Anderson, R. E. (2018). Multivariate data analysis (8 ${ }^{\text {th }}$ ed.). Cengage Learning EMEA.

Hristov, I., \& Chirico, A. (2019). The role of sustainability key performance indicators (KPIs) in implementing sustainable strategies. Sustainability, 11, 5742. doi:10.3390/su11205742

Imbrișcă, C. I., \& Toma, S. G. (2020). Social responsibility, a key dimension in developing a sustainable higher education institution: The case of students' motivation. Amfiteatru Economic, 22(54), 447-461. doi: 10.24818/EA/2020/54/447

Jayabalan, J., Dorasamy, M., \& Raman, M. (2021). Reshaping higher educational institutions through frugal open innovation. Journal of Open Innovation: Technology, Market, and Complexity, 7(2), 145. https://doi.org/10.3390/joitmc7020145

Junior, A. S., Martins-Silva, P. O., de Araujo Vasconcelos, K. C., da Silva, V. C., de Brito, S. L. M., S., \& Monteiro, J. M. R. (2019). Sustainability and corporate social responsibility in the opinion of undergraduate students in management programs: Between the concrete and the abstract. Journal of Cleaner Production, 207, 600-617. https://doi.org/10.1016/j.jclepro.2018.10.011

Juščius, V., \& Snieška, V. (2008). Influence of corporate social responsibility on competitive abilities of corporations. Inzinerine Ekonomika-Engineering Economics, 58(3), 34-44. 
Kouatli, I. (2019). The contemporary definition of university social responsibility with quantifiable sustainability. Social Responsibility Journal, 15(7), 888-909. doi:10.1108/SRJ-10-2017-0210

Larrán, M., Andrades, J., \& Herrera, J. (2018). An examination of attitudes and perceptions of Spanish business and accounting students toward corporate social responsibility and sustainability themes. Spanish Accounting Review, 21(2), 196-205. https://doi.org/10.1016/j.rcsar.2018.02.001

Larran-Jorge, M., Hernandez, A. L., \& Cejas, M. Y. C. (2012). Stakeholder expectations in Spanish public universities: An empirical study. International Journal of Humanities and Social Sciences, 2(10), 1-13.

Latif, K. F. (2018). The development and validation of stakeholder-based scale for measuring university social responsibility (USR). Social Indicators Research, 140(2), 511-547. doi.org/10.1007/s11205-017-1794-y

Latif, K. F., Bunce, L., \& Ahmad, M. S. (2021). How can universities improve student loyalty? The roles of university social responsibility, service quality, and "customer" satisfaction and trust. International Journal of Educational Management, 35(4), 815829. https://doi.org/10.1108/IJEM-11-2020-0524

Leal Filho, W., Shiel, C., Paço, A., Mifsud, M., Avila, L.V., Brandli, L.L., et al., (2019). Sustainable development goals and sustainability teaching at universities: Falling behind or getting ahead of the pack? Journal of Cleaner Production, 232, 285-294. https://doi.org/10.1016/j.jclepro.2019.05.309

Lu, J., Ren, L., Zhang, C., Wang, C., Petkeviciute, N., \& Streimikis, J. (2020). Gender difference in corporate social responsibility implementation in Lithuanian SMEs. Oeconomia Copernicana, 11(3), 549-569. https://doi.org/10.24136/oc.2020.023

Mohamad, B., Ismail, A. R., \& Bidin, R. (2017). Corporate identity management and employee brand support: Enhancing marketization in higher education sector. Jurnal Komunikasi: Malaysian Journal of Communication, 33(3), 178-195. https://doi.org/10.17576/JKMJC-2017-3303-11

Saleh, M. S., Kasim, M. N., Tukur, N. A., Mukhiar, S. N., \& Balaraman, R. A. (2021). Sustainable universities as brand marketing for universities: A case of Universiti Sains Malaysia. Media Watch, 12(1), 127-148. doi: 10.15655/mw/2021/v12i1/205463

Mohr, L. A., Webb, D. J., \& Harris, K. E. (2001). Do consumers expect companies to be socially responsible? The impact of corporate social responsibility on buying behavior. Journal of Consumer Affairs, 35(1), 45-72. https://doi.org/10.1111/j.17456606.2001.tb00102.x

Pätäri, S., Arminen, H., Albareda, L., Puumalainen, K., \& Toppinen, A. (2017). Student values and perceptions of corporate social responsibility in the forest industry on the road to a bioeconomy. Forest Policy and Economics, 85(April), 201215. https://doi.org/10.1016/j.forpol.2017.10.009

Păunescu, C., Drăgan, D., \& Găucă, O. (2017). Examining obligations to society for QS Stars best ranked universities in social responsibility. Management \& Marketing. Challenges for the Knowledge Society, 12(4), 551-570. doi: 10.1515/mmcks-2017-0033.

Plungpongpn, J., Tiangsoongnern, L., \& Speece, M. (2016). University social responsibility and brand image of private universities in Bangkok. International Journal of Educational Management, 30(4), 571-591. doi:10.1108/IJEM-10-2014-0136 
Rad, H. F., Parsa, A., Shahi, S., \& Bahrami, M. (2020). University social responsibility and organizational factors for their implementation. FWU Journal of Social Sciences, 14(3), 70-87.

Ramos-Monge, E. L., Llinàs-Audet, X., \& Barrena-Martínez, J. (2017). Universities as corporate entities: The role of social responsibility in their strategic management. In Corporate Governance and Strategic Decision Making, 199-215.

https://dx.doi.org/10.5772/intechopen.69931

Saunders, M. N. K., Lewis, P., \& Thornhill, A. (2019). Research methods for business students. ( $8^{\text {th }}$ ed.). Harlow: Pearson Education Limited.

Sekaran, U., \& Bougie, R. (2016). Research methods for business: A skill building approach $\left(7^{\text {th }}\right.$ ed.). New Jersey: John Willey and Sons, Inc.

Senin, M. A., Halim, H., \& Ali, A. A. E. R. (2019). Corporate social responsibility (CSR) for education in Malaysia: A systematic literature review. International Journal of Psychosocial Rehabilitation, 23(3), 631-637.

Siddiqi, A. F. (2014). An observatory note on tests for normality assumptions. Journal of Modelling Management, 9(3), 290-305. https://doi.org/10.1108/JM2-04-2014-0032

Spodarczyk, E., \& Szelągowska-Rudzka, K. (2019). Socially responsible university from the perspective of a student as a stakeholder - a pilot study report. Management, 23(2), 88-97. https://doi.org/10.2478/manment-2019-0020

Sunardi. (2019). University social responsibility, university image, and higher education performance. Indonesian Management and Accounting Research, 18(1), 62-78. doi: 10.25105/imar.v18i1.408

Symaco, L. P., \& Tee, M. Y. (2019). Social responsibility and engagement in higher education: Case of the ASEAN. International Journal of Educational Development, 66, 184-192. https://doi.org/10.1016/j.ijedudev.2018.10.001

Teixeira, A., Ferreira, M. R., Correia, A., \& Lima, V. (2018). Students' perceptions of corporate social responsibility: Evidences from a Portuguese higher education institution. International Review on Public Nonprofit Marketing, 15, 235-252. https://doi.org/10.1007/s12208-018-0199-1

Ugwuozor, F. O. (2020). Students' perception of corporate social responsibility: Analyzing the influence of gender, academic status, and exposure to business ethics education. Business Ethics, the Environment \& Responsibility, 29(4), 737-747. https://doi.org/10.1111/beer.12306 